\title{
APLIKASI FAKTUR PAJAK ELEKTRONIK (E-FAKTUR) DALAM RANGKA PENGUKURAN TINGKAT KEPATUHAN WAJIB PAJAK PADA KANTOR PELAYANAN PAJAK
}

\author{
Agustin Tyasmminingsih \\ EF Sinergy Consultant \\ JL Ketintang Residance RK. Residence No. 3 Surabaya \\ Email:ningagustin17@gmail.com
}

Abstract

E-Invoicing is invoice tax that is created through electronic application or system and provided by Directorate General of Taxation. Implementation of einvoicing can encourage self-assessment to be better. Because of that, researcher intended to find out the level of taxpayer compliance in reporting of Value Added Tax (VAT) by latest application of electronic tax invoicing (E-Invoicing). This type of research is descriptive quantitative research that was describing numeric data from the questionnaire answers of respondent with likert scale measurement that was given by researcher. Therefore, the data could be processed by SPSS 17 for windows. Independent Variable in this research were urgency of the implementation of e-invoicing $\left(X_{p}\right)$, the aim of e-invoicing $\left(X_{2}\right)$, socialization to $W P\left(X_{3}\right)$, constraint of e-invoicing implementation $\left(X_{4}\right)$, speed $\left(X_{5}\right)$, accuracy $\left(X_{\sigma}\right)$, space efficiency storage / archiving $\left(X_{7}\right)$, and religiosity $\left(X_{8}\right)$. The Dependent Variable were $Y_{1}$ (formal taxpayer compliance) and $Y_{2}$ (material taxpayer compliance). Based on the results of multiple regression analysis of this study are implementation of e-invoicing simultaneously (together) with variable $X_{1}-X_{8}$ has significant effect on $Y_{1}$ (formal taxpayer compliance) and $Y_{2}$ (material taxpayer compliance). Partially (t test) result showed socialization to wajib pajak $\left(X_{3}\right)$ has a significant influence on the Formal 
Taxpayer Compliance $\left(Y_{1}\right)$. MaterialTaxpayer Compliance $\left(Y_{2}\right)$, only Religiosity $\left(X_{8}\right)$ which has a significant influence to Material Taxpayer Compliance $\left(Y_{2}\right)$.

Keywords: tax, e-invoicing, taxpayer compliance

Abstrak

Faktur Pajak yang berbentuk elektronik, yang selanjutnya disebut e-Faktur, adalah Faktur Pajak yang dibuat melalui aplikasi atau sistem elektronik yang ditentukan dan/atau disediakan oleh Direktorat Jenderal Pajak. Penerapan E-Faktur dapat mendorong terciptanya pelaksanaan self assessment dengan lebih baik. Karena hal ini, Peneliti bermaksud untuk mengetahui seberapa besar tingkat kepatuhan Wajib Pajak dalam melaporkan Pajak Pertambahan Nilai dengan aplikasi terbaru yaitu faktur pajak elektronik (e-faktur). Jenis penelitian yang digunakan dalam penelitian ini adalah penelitian kuantitatif deskriptif. Yakni mendeskripsikan data berupa angka, data berupa angka tersebut berasal dari jawaban responden dalam kuisioner yang diberikan oleh peneliti yang sudah diberikan skala pengukuran yakni skala likert sehingga data tersebut dapat diolah lebih lanjut dengan menggunakan SPSS 17 for Windows. Dengan Variabel Independen adalah Urgensi diterapkannya e-faktur $\left(\mathrm{X}_{1}\right)$, Tujuan penerapan e-faktur $\left(\mathrm{X}_{2}\right)$, Sosialisasi kepada wajib pajak $\left(\mathrm{X}_{3}\right)$ Kendala dalam penerapan e-faktur $\left(\mathrm{X}_{4}\right)$, Kecepatan $\left(\mathrm{X}_{5}\right)$, Keakuratan $\left(\mathrm{X}_{6}\right)$, Éfisiensi Ruang Penyimpanan/Pengarsipan $\left(\mathrm{X}_{7}\right)$, dan Religiusitas $\left(\mathrm{X}_{8}\right)$. Untuk Variabel Dependen ada dua yakni: $\mathrm{Y}_{1}$ (kepatuhan wajib pajak Formal) serta $Y_{2}$ (kepatuhan wajib pajak Material). Berdasarkan hasil analisis regresi berganda hasil dari penelitian ini adalah Penerapan e-faktur secara simultan (bersama-sama) dengan variabel $\mathrm{X}_{1}-\mathrm{X}_{8}$ berpengaruh siginifikan terhadap $\mathrm{Y}_{1}$ (kepatuhan wajib pajak Formal) serta $Y_{2}$ (kepatuhan wajib pajak Material). Secara parsial (Uji t) diperoleh hasil bahwa hanya Sosialisasi kepada WP $\left(\mathrm{X}_{3}\right)$ yang memiliki pengaruh signifikan terhadap Kepatuhan Wajib Pajak Formal $\left(\mathrm{Y}_{1}\right)$. Sedangkan untuk Kepatuhan Wajib Pajak Material $\left(\mathrm{Y}_{2}\right)$, hanya Religiusitas $\left(\mathrm{X}_{8}\right)$ yang memiliki pengaruh signifikan terhadap Kepatuhan Wajib Pajak Material $\left(\mathrm{Y}_{2}\right)$.

Kata kunci: pajak, e-faktur, kepatuhan wajib pajak

\section{PENDAHULUAN}

Tonggak Reformasi Perpajakan di Indonesia sudah dimulai sejak disahkannya Undang-Undang Nomor 6 Tahun 1983 tentang Ketentuan Umum dan Tata Cara Perpajakan (KUP), Undang-Undang Nomor 7 Tahun 1983 tentang Pajak Penghasilan, dan Undang-Undang Nomor 8 Tahun 1983 tentang Pajak Pertambahan Nilai dan Pajak Penjualan Barang Mewah (PPN dan PPnBM). Kemudian yang terakhir kali dirubah menjadi Undang-Undang Nomor 16 Tahun 2009 tentang 
Ketentuan Umum tentang dan Tata Cara Perpajakan (KUP), Undang-Undang Nomor 17 Tahun 2000 tentang Pajak Penghasilan dan Undang-Undang Nomor 42 Tahun 2009 tentang PPN dan PPnBM. Niat baik dari Direktorat Jenderal Pajak untuk membuat sistem administrasi perpajakan menjadi lebih baik rupanya tidak cukup sampai di situ. Bergantinya sistem pemungutan pajak dari semula official assessment menjadi self assessment, membawa tantangan tersendiri dari segi pengawasan terhadap kepatuhan pemenuhan perpajakan wajib pajak. Dinamisnya berbagai perubahan dunia bisnis yang diiringi dengan era globalisasi, membuat Direktorat Jenderal Pajak harus cukup adaptif menjawab semua tantangan tersebut, salah satunya adalah dengan terus melakukan pembenahan di bidang administrasi.

Salah satu jenis pajak yang diterapkan di indonesia adalah Pajak Pertambahan Nilai (PPN). Pajak Pertambahan nilai merupakan pengganti dari Pajak Penjualan (PPn), yang berdasarkan pada Undang-Undang Nomor 8 tahun 1983 yang ditetapkan sejak 1 April 1985 sebagaimana telah diubah terakhir kali dengan Undang-Undang Nomor 42 tahun 2009 tentang Pajak Pertambahan Nilai (PPN) dan Pajak Penjualan atas Barang Mewah (PPnBM), sampai sekarang masih berlaku dengan menggunakan Pajak Pertambahan Nilai (PPN). Dasar pemikiran atas Pajak Pertambahan Nilai adalah untuk mengenakan pajak pada tingkat kemampuan masyarakat untuk berkonsumsi, yang pengenaannya dilakukan secara tidak langsung kepada konsumen. (ortax.org)

Pajak Pertambahan Nilai (PPN) yang tergolong sebagai pajak objektif, dipandang sangat terkait erat dengan dunia usaha karena melingkupi "Pengusaha Kena Pajak" yang dijelaskan dalam Undang-Undang PPN sebagai pengusaha yang melakukan penyerahan Barang Kena Pajak dan atau Jasa Kena Pajak. Para Pengusaha Kena Pajak yang diberi kepercayaan untuk memungut PPN, menghitung PPN terutang, serta melaporkannya kepada Kantor Pelayanan Pajak, rupanya belum semua mematuhi kewajibannya. Kasus para Pengusaha Kena Pajak yang menerbitkan Faktur Pajak Fiktif sehingga membuat kerugian kepada keuangan negara, membuat Direktorat Jenderal Pajak akhirnya melakukan reformasi lanjutan, yaitu Reformasi Sistem Administrasi PPN.

Program Reformasi Sistem Administrasi PPN merupakan sebuah "pembenahan" administrasi untuk menangkal ketidakpatuhan PKP dan demi mewujudkan sistem administrasi DJP yang lebih efektif dan efisien. Program ini sudah berlangsung sejak tahun 2011 dan dituangkan dalam roadmap DJP sampai tahun 2015. Adapun rencana pembenahan administrasi PPN meliputi Evaluasi Bentuk Pelaporan SPT, Registrasi Ulang PKP, Evaluasi Sistem Value Added Tax (VAT) dan pertimbangan untuk mengadopsi sistem Pajak Konsumsi (GST-Goods and Sales Tax), Kewajiban Penggunaan e-SPT bagi Wajib Pajak Badan dan PKP individu tertentu, kenaikan batas omzet bagi pengusaha kecil, serta implementasi Faktur Pajak elektronik ( $e$ faktur). 
Faktur Pajak yang berbentuk elektronik, yang selanjutnya disebut e-Faktur, adalah Faktur Pajak yang dibuat melalui aplikasi atau sistem elektronik yang ditentukan dan/atau disediakan oleh Direktorat Jenderal Pajak (Pasal 1 ayat (1) PER-16/ $\mathrm{PJ} / 2014)$. Aplikasi atau sistem elektronik yang ditentukan dan/atau disediakan oleh Direktorat Jenderal Pajak sebagaimana dimaksud pada ayat (1) dilengkapi dengan petunjuk penggunaan (manual user) yang merupakan satu kesatuan dengan aplikasi atau sistem elektronik tersebut (Pasal 1 ayat (3) PER-16/PJ/2014).

Faktur Pajak Elektronik dilatar belakangi oleh 2 (dua) hal utama, yaitu adanya penyalahgunaan Faktur Pajak dan Tingginya beban administrasi Faktur Pajak. Oleh karena itu, melalui Peraturan Menteri Keuangan Nomor 151/PMK.03/2013 yang dijabarkan lebih lanjut dengan Peraturan Direktur Jenderal Pajak Nomor 16/PJ/ 2014, maka dibuatlah mekanisme faktur pajak elektronik tersebut. Perubahannya mencakup : Format Faktur Pajak yang telah ditentukan sistem, Bentuk tanda tangan elektronik, Lembaran faktur pajak yang tidak perlu dicetak, PKP yang membuat hanya yang ditetapkan oleh Dirjen Pajak, Jenis transaksi yang dibuatkan faktur pajak kini terbatas pada penyerahan BKP dan JKP saja, dan Pelaporan menggunakan aplikasi yang sama dengan pembuatan e-faktur.

Penerapan E-faktur dapat mendorong terciptanya pelaksanaan self assessment dengan lebih baik lagi dan Wajib Pajak mempunyai kesadaran untuk melaksanakan hak dan kewajiban perpajakannya sesuai dengan ketentuan perpajakan yang berlaku. Aktivitas ini tentu saja bermuara terhadap penerimaan pajak melalui pencegahan penerbitan Faktur Pajak Fiktif dan kerugian yang diakibatkan oleh penerbitan Faktur Pajak Fiktif dapat ditekan.

Tujuan diperbaharuinya sistem pajak dengan ditambahkannya e-faktur diharapkan dapat meningkatkan kepatuhan pajak juga dapat meningkatkan kepercayaan masyarakat terhadap administrasi perpajakan, serta produktivitas pegawai pajak yang tinggi. Sedangkan tujuan penggunaan teknologi informasi dalam perpajakan adalah menghemat waktu, mudah, dan akurat. Dengan penggunaan teknologi informasi dalam administrasi perpajakan diharapkan dapat meningkatkan pelayanan terhadap Wajib Pajak, baik dari segi kualitas maupun waktu sehingga lebih efektif. Berikut tabel jumlah frekuensi sosalisasi dan jumlah Wajib Pajak di KPP Pratama Surabaya Wonocolo.

Tabel 1. Frekuensi Sosialisasi KPP Pratama Surabaya Wonocolo Tahun 2015

\begin{tabular}{lccr}
\hline Jenis Kegiatan & Tahun 2013 & Tahun 2014 & Tahun 2015 \\
\hline Penyuluhan Langsung & $40 \mathrm{x}$ & $40 \mathrm{x}$ & $41 \mathrm{x}$ \\
Penyuluhan tidak Langsung & $2 \mathrm{x}$ & $2 \mathrm{x}$ & $3 \mathrm{x}$ \\
Penyuluhan Lain & $10 \mathrm{x}$ & $16 \mathrm{x}$ & $37 \mathrm{x}$ \\
\hline Jumlah Frekuensi & $52 \mathrm{x}$ & $58 \mathrm{x}$ & $81 \mathrm{x}$ \\
\hline Sumber: KPP Pratama Surabaya Wonocolo 2016 & &
\end{tabular}


Tabel 2. Jumlah Wajib Pajak

\begin{tabular}{ccccc}
\hline No & Tahun & Wajib Pajak & WP OP & WP Badan \\
\hline $\mathbf{1}$ & 2014 & 6.999 & 356 & 6.643 \\
$\mathbf{2}$ & 2015 & 4.736 & 233 & 4.503 \\
$\mathbf{3}$ & 2016 & 2.678 & 109 & 2.569 \\
\hline
\end{tabular}

Sumber: KPP Pratama Surabaya Wonocolo 2016

Penelitian sebelumnya (Prahaji dkk, 2015). Peneliti menemukan bahwa sistem e-nofa menunjukkan hasil yang signifikan dalam mencegah penggunaan maupun penerbitan faktur pajak fiktif di Kantor Pelayanan Pajak Wajib Pajak Besar Tiga, sedangkan hambatan dari penerapan program ini adalah ketergantungan sistem dan koneksi jaringan internet, Wajib Pajak yang masih harus datang ke Kantor Pelayanan Pajak, dan tingkat pemahaman serta kelalaian Wajib Pajak. Penelitian sebelumnya juga dilakukan oleh (Gisbu, dkk, 2015). Dalam Penerapan Penomoran Faktur". Berdasarkan hasil penelitian menunjukkan bahwa program e-nofa PPN berpengaruh secara signifikan terhadap tingkat Kepatuhan Pengusaha Kena Pajak dalam penerapan penomoran nomor faktur. Dari latar belakang di atas maka permasalahannya adalah:

1. Apakah penerapan aplikasi Elektronik Faktur Pajak (e-faktur) berpengaruh terhadap tingkat kepatuhan Wajib Pajak Formal dalam melaksanakan kewajiban perpajakannya terkait pembuatan dan pelaporan faktur pajak pada KPP Pratama Surabaya Wonocolo?

2. Apakah penerapan aplikasi Elektronik Faktur Pajak (e-faktur) berpengaruh terhadap tingkat kepatuhan Wajib Pajak Material dalam melaksanakan kewajiban perpajakannya terkait pembuatan dan pelaporan faktur pajak pada KPP Pratama Surabaya Wonocolo?

\section{LANDASAN TEORI}

Pajak menurut Undang-Undang Nomor 16 tahun 2009 tentang perubahan keempat atas Undang-Undang Nomor 6 tahun 1983 tentang Ketentuan Umum dan Tata Cara Perpajakan pada Pasal 1 ayat 1 berbunyi pajak adalah kontribusi wajib kepada negara yang terutang oleh orang pribadi atau badan yang bersifat memaksa berdasarkan Undang-Undang, dengan tidak mendapatkan imbalan secara langsung dan digunakan untuk keperluan negara bagi sebesar-besarnya kemakmuran rakyat. Definisi atau pengertian pajak menurut prof. Dr. Rochmat Soemitro, SH, sebagaimana dikutip oleh Mardiasmo (2013: 1) dalam perpajakan edisi revisi, menyebutkan bahwa: "pajak adalah iuran rakyat kepada kas negara berdasarkan undang-undang (yang dapat dipaksakan) dengan tiada mendapat jasa timbul (kontraprestasi) yang langsung dapat ditunjukkan dan yang digunakan untuk membayar pengeluaran umum”. Pengertian Pajak Pertambahan Nilai dalam Resmi 
(2014: 5) Pajak Pertambahan Nilai (PPN) merupakan pajak tidak langsung, artinya pajak yang pada akhirnya dapat dibebankan atau dialihkan kepada orang lain atau pihak ketiga. Pihak-pihak yang mempunyai kewajiban memungut, menyetor, dan melaporkan terdiri atas: (1) Pengusaha Kena Pajak/PKP, (2) Pengusaha kecil yang memilih untuk dikukuhkan sebagai PKP, (3) Orang pribadi atau badan yang memanfaatkan BKP tidak berwujud dan/atau JKP dari luar daerah pabean di dalam daerah pabean (4) Orang pribadi atau badan yang melakukan impor barang kena pajak, (5) Pengusaha kena pajak yang melakukan penjualan barang yang menurut tujuan semula tidak untuk dijual kembali, (6) Orang pribadi atau badan yang melakukan pembangunan rumahnya sendiri dengan persyaratan tertentu, (7) Pemungut pajak yang ditunjuk oleh pemerintah.

Pengusaha Kena Pajak, Dalam Pasal 1 butir 15 Undang-Undang PPN No.42 Tahun 2009 Pengusaha Kena Pajak adalah pengusaha yang melakukan penyerahan Barang Kena Pajak dan/atau penyerahan Jasa Kena Pajak yang dikenai pajak berdasarkan Undang-Undang ini, maka diperbolehkan. Untuk menjadi PKP, maka harus mengisi formullir melalui online yang sudah disediakan oleh Direktorat Jendaral Pajak. Faktur pajak, menurut (Waluyo, 2011:84) Faktur pajak merupakan faktur yang dipergunakan sebagai bukti pungutan pajak dan sebagai sarana untuk mengkreditkan pajak masukan. Untuk setiap penyerahan BKP atau penyerahan JKP oleh Pengusaha Kena Pajak harus dibuat satu faktur pajak. Faktur pajak harus diisi secara lengkap, jelas, dan benar serta ditandatangani oleh pihak yang ditunjuk oleh Pengusaha Kena Pajak (PKP) untuk menandatanganinya. Jenis Faktur Pajak Menurut Waluyo (2012: 317) jenis Faktur Pajak adalah sebagai berikut: faktur pajak standar, faktur pajak gabungan, faktur pajak khusus.

\section{E-FAKTUR}

Menteri Keuangan telah menerbitkan Peraturan Menteri Keuangan Nomor PMK-151/PMK.011/2013 tentang Tata Cara Pembuatan dan Pembetulan atau Penggantian Faktur Pajak. Dalam PMK tersebut diatur bahwa Faktur Pajak terdiri dari Faktur Pajak berbentuk elektronik (e-Faktur) dan Faktur Pajak berbentuk kertas (hardcopy). Pengertian Faktur Pajak elektronik (e-Faktur) menurut Pasal 1(1) Peraturan Direktur Jenderal Pajak Nomor PER-16/PJ/2014 tentang Tata Cara Pembuatan dan Pelaporan Faktur Pajak Berbentuk Elektronik ialah Faktur Pajak yang dibuat melalui aplikasi atau sistem elektronik yang ditentukan dan/atau disediakan oleh DJP. Berikut adalah tabel perbedaan antara faktur pajak manual dengan faktur pajak elektronik, yaitu: 
Tabel 3. Perbedaan Faktur Pajak Manual dan e-faktur

\begin{tabular}{|c|c|c|c|}
\hline No & Keterangan & Faktur Pajak Manual & E-Faktur \\
\hline 1 & Format/lay out & $\begin{array}{l}\text { Bebas tidak ditentukan dan dapat } \\
\text { mengikuti contoh di lampiran PER- } \\
\text { 24/PJ/2014 }\end{array}$ & $\begin{array}{l}\text { Ditentukan oleh aplikasi/sistem yang } \\
\text { ditentukan dan atau } \\
\text { disediakan oleh DJP }\end{array}$ \\
\hline 2 & $\begin{array}{l}\text { Tanda tangan } \\
\text { pegawai/pejabat yang } \\
\text { ditunjuk oleh PKP }\end{array}$ & Tanda tangan basah diatas FP Kertas & $\begin{array}{l}\text { Tanda tangan elektronik berbentuk QR } \\
\text { code }\end{array}$ \\
\hline 3 & $\begin{array}{l}\text { Bentuk dan jumlah } \\
\text { lembar }\end{array}$ & $\begin{array}{l}\text { Diwajibkan berbentuk kertas dan } \\
\text { jumlah lembar diatur }\end{array}$ & $\begin{array}{l}\text { Tidak diwajibkan untuk dicetak dalam } \\
\text { bentuk kertas }\end{array}$ \\
\hline 4 & PKP yang membuat & Seluruh PKP & $\begin{array}{l}\text { PKP yang ditetapkan oleh DJP (per 1Juli } \\
\text { 2014) }\end{array}$ \\
\hline 5 & Jenis Transaksi & Seluruh & Penyerahan $\mathrm{BKP} / \mathrm{JKP}$ saja \\
\hline 6 & $\begin{array}{l}\text { Prosedur Lapor/upload } \\
\text { dan persetujuan DJP }\end{array}$ & - & $\begin{array}{l}\text { e-Faktur dilaporkan ke DJP dengan cara } \\
\text { upload dan mendapat persetujuan DJP }\end{array}$ \\
\hline 7 & Pelaporan SPT PPN & Menggunakan aplikasi tersendiri & $\begin{array}{l}\text { Menggunakan aplikasi yang sama dengan } \\
\text { aplikasi pembuatan } e \text {-Faktur }\end{array}$ \\
\hline
\end{tabular}

\section{Kepatuhan Membayar Pajak dalam Prespektif Islam}

Pada masa pemerintahannya Rasulullah SAW menerapkan jizyah, yakni pajak yang dibebankan kepada orang-orang nonmuslim, khususnya ahli kitab, sebagai jaminan perlindungan jiwa, harta milik, kebebasan menjalankan ibadah, serta pengecualian dari wajib militer. Besarnya jizyah adalah satu dinar pertahun untuk setiap orang laki-laki dewasa yang mampu membayar. Perempuan, anak-anak, pengemis, pendeta, orang tua, penderita sakit jiwa dan semua yang menderita penyakit dibebaskan dari kewajiban jizyah. Disamping itu, Rasulullah SAW juga menerapkan sistem kharaj, yaitu pajak tanah yang dipungut dari kaum nonmuslim ketika wilayah Khaibar ditaklukkan, tanah hasil taklukan diambil alih oleh kaum muslimin, dan pemilik lamanya diberi hak untuk mengolah tanah tersebut dengan status sebagai penyewa dan bersedia memberikan separuh hasil produksinya kepada negara.

Seperti yang tertera dalam pengetian pajak yaitu pajak sifatnya wajib dan dapat dipaksakan oleh pemerintah, dengan penerapan Self Assessment System Wajib Pajak harusnya sudah paham bahwa pemerintah memberikan amanah sepenuhnya kepada Wajib Pajak untuk melaksanakan kewajiban perpajakannya sendiri meliputi, mendaftar, menghitung, membayar dan melaporkan. Maka seperti yang tertera pada al Quran surat An-nisa ayat 59 yang berbunyi:

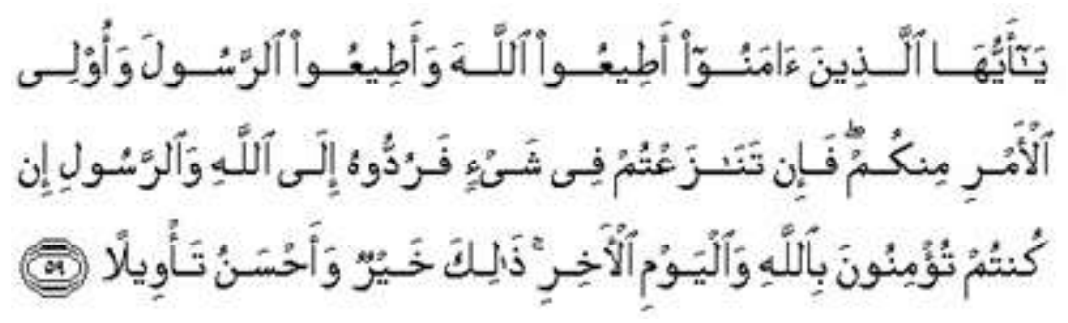


Artinya:

"Hai orang-orang yang beriman, taatilah Allah dan taatilah Rasul (Nya), dan ulil amri di antara kamu. Kemudian jika kamu berlainan pendapat tentang sesuatu, maka kembalikanlah ia kepada Allah (Al Quran) dan Rasul (sunnahnya), jika kamu benar-benar beriman kepada Allah dan hari kemudian. Yang demikian itu lebih utama (bagimu) dan lebih baik akibatnya". (QS. An-nisa': 59)

Ayat ini mengatakan kepada kaum mukmin, selain taat kepada Tuhan dan Rasulnya, maka haruslah kalian taat kepada para pemimpin yang adil. Karena ketaatan itu merupakan kelaziman iman kepada Tuhan dan hari kiamat. Dalam riwayat sejarah disebutkan, bahwa Rasul SAW ketika berangkat ke perang Tabuk beliau melantik Imam Ali as sebagai penggantinya di Madinah.

\section{METODE PENELITIAN}

\section{Jenis dan Pendekatan Penelitian}

Jenis penelitian yang digunakan dalam penelitian ini adalah penelitian kuantitatif deskriptif. Yakni mendeskripsikan data berupa angka, data berupa angka tersebut berasal dari jawaban responden dalam kuisioner yang diberikan oleh peneliti yang sudah diberikan skala pengukuran yakni skala likert sehingga data tersebut dapat diolah lebih lanjut dengan menggunakan SPSS 17 for Windows. Menurut Arikunto (2010:27) metode kuantitatif sesuai dengan namannya banyak dituntut menggunakan angka, mulai dari pengumpulan data, penafsiran terhadap data tersebut serta penampilan dari hasilnya. Data kuantitatif yaitu data yang berbentuk angka yang sifatnya dapat dihitung dan diukur jumlahnya untuk diolah menggunakan metode statistik.

\section{PEMBAHASAN}

\section{Pembahasan Data Hasil Penelitian Kepatuhan Wajib Pajak Formal}

Berdasarkan hasil penelitian yang sudah dibahas sebelumnya menunjukkan bahwa variabel independen X1-X8 secara simultan atau bersama-sama berpengaruh signifikan terhadap variabel dependen Y1 (Kepatuhan Wajib Pajak Formal). Kemudian untuk hasil analisis secara parsial (uji t) dapat disimpulkan bahwa Urgensi diterapkannya e-faktur (X1) belum memiliki pengaruh positif dalam mempengaruhi Tingkat Kepatuhan Wajib Pajak Formal (Y1) hal ini dikarenakan penerapan penggunaan aplikasi e-faktur bagi Pengusaha Kena Pajak masih terlalu singkat yang disebabkan sistem belum bekerja secara maksimal dalam peningkatkan pelayanan KPP kepada Wajib Pajak. Tujuan penerapan e-faktur (X2) belum memiliki pengaruh positif dalam mempengaruhi Tingkat Kepatuhan Wajib Pajak Formal (Y1) hal ini 
dikarenakan penerapan e-Faktur sebagai perbaikan sistem administrasi PPN yang selama ini masih menerapkan sistem manual dalam penerbitan faktur pajak oleh wajib pajak. Aplikasi e-faktur masih belum sempurna karena wajib pajak harus selalu melakukan upgrade system. Dalam penelitian yang dilakukan oleh Gisbu dkk (2015: 10) menunjukkan dimana tingkat kepatuhan wajib pajak dalam penerapan aplikasi e-Nofa hanya mempunyai pengaruh sebesar 31,3\%, sedangkan dalam penelitian ini besarnya pengaruh aplikasi e-faktur yang merupakan suatu bentuk modernisasi/perbaikan dari sistem e-Nofa terhadap tingkat kepatuhan wajib pajak memiliki pengaruh sebesar 37,4\%. Hal ini berarti adanya peningkatan kepatuhan wajib pajak sebesar $6 \%$ setelah adanya modernisasi/perbaikan sistem dalam hal pembuatan dan pelaporan pajak pertambahan nilai dari aplikasi $e$-Nofa menjadi aplikasi e-faktur.

Untuk variabel Sosialisasi kepada WP (X3) memiliki pengaruh positif dalam mempengaruhi Tingkat Kepatuhan Wajib Pajak Formal (Y1) hal ini disebabkan dengan adanya sosialisasi yang kerap diadakan oleh KPP Pratama Surabaya Wonocolo. Selanjutnya variabel Kendala dalam penerapan e-faktur (X4) belum memiliki pengaruh positif dalam mempengaruhi Tingkat Kepatuhan Wajib Pajak Formal (Y1) hal ini diperkuat dengan adanya nilai beta (b) negatif pada uji regresi dengan menggunakan aplikasi SPSS 17.0. Variabel Kecepatan (X5) belum memiliki pengaruh positif dalam mempengaruhi Tingkat Kepatuhan Wajib Pajak Formal (Y1), hal ini dikarenakan masih ada wajib pajak yang kesulitan dalam menggunakan aplikasi $e$-faktur, terutama pada pengoperasian aplikasi (proses penginputan data) masih cukup rumit bagi wajib pajak.

Variabel Keakuratan (X6) belum memiliki pengaruh positif dalam mempengaruhi Tingkat Kepatuhan Wajib Pajak Formal (Y1), hal ini dikarenakan masih ada Wajib Pajak yang melakukan kesalahan dalam proses penginputan atau pengolahan data sedangkan data sudah terlanjur di upload dan di approval oleh sistem DJP, sehingga Wajib Pajak perlu membuat faktur pajak batal atau faktur pajak pengganti yang mekanismenya masih membingungkan dan cukup rumit dalam aplikasi e-faktur. Variabel Efisiensi Ruang Penyimpanan/Pengarsipan (X7) belum memiliki pengaruh positif dalam mempengaruhi Tingkat Kepatuhan Wajib Pajak Formal (Y1). Untuk penyimpanan/pengarsipan dalam aplikasi e-faktur memang sudah terproteksi dan tingkat keamanannya cukup tinggi, karena semua terkomputerisasi dan selalu membutuhkan koneksi internet untuk mengaksesnya.

Variabel Religiusitas (X8) belum memiliki pengaruh positif dalam mempengaruhi Tingkat Kepatuhan Wajib Pajak Formal (Y1) hal ini diperkuat dengan adanya nilai beta (b) negatif pada uji regresi dengan menggunakan aplikasi SPSS 17.0. Dari hasil olahan data statistik menunjukkan nilai koefisien b (beta) variabel religiusitas memiliki nilai negatif yang berarti bahwa pengaruh variabel religiusitas berbanding terbalik terhadap tingkat kepatuhan wajib pajak, semakin wajib pajak tersebut taat beragama (variabel X8.1 Beribadah tepat waktu dan mendekatkan diri pada Sang 
Pencipta, X8.2 Melakukan kebaikan akan dibalas dengan kebaikan pula, X8.3 Mengikuti kajian- kajian tentang keagamaan dan X8.4 Menjalankan perintahNYA dan menjauhi laranganNYA) maka semakin tidak patuh wajib pajak tersebut dalam menjalankan kewajiban perpajakannya yaitu kewajiban formal (Y1). Hal ini didukung dengan peristiwa yang terjadi pada tahun 2012 ulama Nahdhatul Ulama (NU) mengatakan bahwa pembayaran pajak bukan kewajiban yang disyariatkan agama sebagaimana zakat, melainkan bagian dari kewajiban untuk taat kepada pemerintah (ulil amri), termasuk taat terhadap aturan yang dibuat. Sebenarnya NU tidak mempermasalahkan kewajiban membayar pajak selama pengelolaan pajak dilakukan dengan amanah, namun jika terbukti tidak amanah maka kewajiban itu dianggap perlu ditinjau ulang. Hal ini terjadi terkait dengan terungkapnya berbagai kasus penyelewengan dan korupsi di sektor yang merupakan pemasukan terbesar bagi negara tersebut. (beritasatu.com).

Dalam al Quran surat An-nisa' ayat 59 yang artinya "Hai orang-orang yang beriman, ta'atilah Allah dan ta'atilah Rasul (Nya), dan ulil amri di antara kamu. Kemudian jika kamu berlainan pendapat tentang sesuatu, maka kembalikanlah ia kepada Allah (al Quran) dan Rasul (sunnahnya), jika kamu benar-benar beriman kepada Allah dan hari kemudian. Yang demikian itu lebih utama (bagimu) dan lebih baik akibatnya." Dalam ayat tersebut telah disebutkan bahwasannya “...jika kamu berlainan pendapat tentang sesuatu, maka kembalikanlah ia kepada Allah (al Quran) dan Rasul (Sunnahnya)..." berlainan pendapat disini adalah pemerintah boleh memungut pajak kepada rakyatnya asalkan digunakan sebagaimana mestinya untuk kepentingan dan kemakmuran rakyat bukan untuk digunakan untuk kepentingan pribadi (korupsi), jika korupsi terus dilakukan oleh pemerintah (ulil amri) maka rakyat boleh untuk menuntut dan tidak taat atas apa yang diwajibkan pemerintah.

\section{Pembahasan Data Hasil penelitian Kepatuhan Wajib Pajak Material}

Berdasarkan hasil penelitian yang sudah dibahas sebelumnya menunjukkan bahwa variabel independen X Urgensi diterapkannya e-faktur (X1), Tujuan penerapan e-faktur (X2), Sosialisasi kepada WP (X3), Kendala dalam penerapan e-faktur (X4), Kecepatan (X5), Keakuratan (X6), Efisiensi Ruang Penyimpanan/ Pengarsipan (X7), Religiusitas (X8), secara simultan atau bersama-sama berpengaruh signifikan terhadap variabel dependent Y2 (Kepatuhan Wajib Pajak Material).

Hasil analisis secara parsial (uji t) dapat disimpulkan bahwa Urgensi diterapkannya e-faktur (X1), Tujuan penerapan e-faktur (X2), Sosialisasi kepada WP (X3), Kendala dalam penerapan e-faktur (X4), Kecepatan (X5), Keakuratan (X6) dan Efisiensi Ruang Penyimpanan/Pengarsipan (X7), belum memiliki pengaruh positif dalam mempengaruhi Tingkat Kepatuhan Wajib Pajak Material (Y2). Dalam pembahasan data hasil penelitian kepatuhan wajib pajak formal juga telah diketahui 
bahwasannya variabel yang telah tersebut diatas memang belum memiliki pengaruh terhadap tingkat kepatuhan wajib pajak formal sebagaimana telah dijelaskan pula alasannya, terkecuali untuk variabel sosialisasi kepada wajib pajak yang memiliki pengaruh signifikan karena pihak KPP sangat gencar untuk melakukan sosialisasi, terhitung selama pertengahan tahun 2015 hingga akhir tahun 2015 telah diadakan workshop dan seminar tentang aplikasi e-faktur sebanyak 41 kali.

DJP telah melakukan sosialisasi secara meluas mengenai penerapan e-faktur kepada wajib pajak namun, masih ada wajib pajak belum melakukan permohonan NSFP dengan benar, serta belum mengisi data faktur pajak dan menghitung PPN dengan benar, lengkap dan jelas.

Kemudian untuk hasil analisis secara parsial (uji t) dapat disimpulkan bahwa hanya variabel Religiusitas (X8) yang memiliki pengaruh signifikan terhadap variabel dependen Y2 (Kepatuhan Wajib Pajak Material), hal ini berarti bahwa orang yang taat beragama akan cenderung bersikap jujur seperti yang tercermin dalam butir pernyataan Y2.1 Melakukan permohonan NSFP dengan benar, Y2.2 Mengisi data faktur pajak dengan benar, lengkap dan jelas serta Y2.3 Menghitung PPN dengan benar, lengkap dan jelas. Seseorang akan melakukan pernyataan tersebut dengan benar dan jujur sebagaimana DJP telah menerapkan self assesment system dimana Wajib Pajak diberikan kepercayaan untuk melakukan kewajiban pajak materialnya yaitu menghitung, menyetor dan melaporkan kewajiban perpajakannya. Sebagaimana dalam al Quran surat At-taubah ayat 119 yang artinya "Hai Orang-orang yang beriman, bertaqwalah kepada Allah, dan hendaklah kamu bersama orangorang yang benar". Makna dari ayat tersebut adalah perintah untuk berperilaku jujur dan selalu bersama-sama dengan orang-orang yang benar, karena yang seperti itulah termasuk orang-orang yang beriman kepada Allah.

\section{SIMPULAN}

Berdasarkan hasil uji regresi berganda maka secara bersama-sama (simultan) aplikasi $e$-faktur berpengaruh secara signifikan terhadap tingkat kepatuhan wajib pajak formal, akan tetapi pada uji t (parsial) hanya sosialisasi kepada Wajib Pajak yang mempunyai pengaruh signifikan. Berdasarkan hasil uji regresi berganda maka secara bersama-sama (simultan) aplikasi e-faktur berpengaruh secara signifikan terhadap tingkat kepatuhan wajib pajak material, akan tetapi pada uji $\mathrm{t}$ (parsial) hanya religiusitas yang mempunyai pengaruh signifikan.

\section{DAFTAR PUSTAKA}

al Quran dan Terjemahan

Arikunto, Suharsimi. 2010. Prosedur Penelitian Suatu Pendekatan Praktek. Edisi Revisi 2010. Jakarta: PT. Rineka Cipta. 
Azizah, Nur. 2014. Pengaruh Penerapan Teknologi Informasi (e-system) terhadap Kepatuhan Wajib Pajak pada KPP Madya Malang. Skripsi. Malang: Universitas Islam Negeri Maulana Malik Ibrahim.

Ghozali, Imam. 2012. Aplikasi Analisis Multivariate dengan Program SPSS. Semarang: Badan Penerbit Universitas Diponegoro.

Gisbu, Oktu Wanda, dkk. 2015. Pengaruh Modernisasi E-Nofa Terhadap Kepatuhan PKP Dalam Penerapan Penomoran Faktur. STIE MDP. Diakses dari http://eprints.mdp. ac.id/1578 (08 Januari 2016)

Hadi, Syamsul. 2006. Metodologi Penelitian Kuantitatif untuk Akuntasi dan Keuanagan. Yogyakarta: EKONISIA.

Indriantoro, Nur dan Bambang Supomo. 2002. Metode Penelitian Bisnis untuk Akuntansi dan Manajemen. Yogyakarta: BPFE.

Keputusan Direktur Jenderal Pajak Nomor KEP-136/PJ/2014 tentang Penetapan Pengusaha Kena Pajak yang Diwajibkan Membuat Faktur Pajak Berbentuk Elektronik.

Lingga, I. Salsalina. 2012. Pengaruh Penerapan e-SPT Terhadap Efisiensi Pengisian SPT Menurut Persepsi Wajib Pajak: Survey Terhadap Pegusaha Kena Pajak Pada KPP Pratama Majalaya. Laporan Penelitian. Universitas Kristen Maranatha Bandung.

Mardiasmo. 2013. Perpajakan Edisi Revisi 2011. Yogjakarta. Penerbit Andi.

Muljono, Djoko 2008, Pajak Pertambahan Nilai Lengkap Dengan Undang-undang. Yogyakarta: Andi Offset.

Nurmatu, Safri. 2005. Pengantar Perpajakan. Jakarta: Kelompok Yayasan Obor Indonesia.

Pengumuman Direktur Jenderal Pajak Nomor PENG-01/PJ.02/2014 tentang Faktur Pajak Berbentuk Elektronik (e-Faktur).

Peraturan Menteri Keuangan PMK Nomor 75/PMK.03/2010 tentang "Nilai Lain Sebagai Dasar Pengenaan Pajak.

Peraturan Menteri Keuangan Nomor 74/PMK.03/2012 tentang "Tata Cara Penetapan dan Pencabutan wajib pajak dengan Kriteria Tertentu Dalam Rangka Pengembalian Pendahuluan Kelebihan Pembayaran Pajak.

Peraturan Menteri Keuangan Nomor PMK-151/PMK.011/2013 tentang Tata Cara Pembuatan dan Pembetulan atau Penggantian Faktur Pajak.

PER-27/PJ/2011 perubahan kedua atas peraturan direktur jenderal pajak nomor per-10/pj/ 2010 tentang dokumen tertentu yang kedudukannya dipersamakan dengan faktur pajak.

PER-24/PJ/2012 Republik Indonesia, Peraturan Direktur Jenderal Pajak Nomor PER-24/PJ/ 2012 tentang Bentuk, Ukuran, Tata Cara Pengisian Keterangan, Prosedur Pemberitahuan Dalam Rangka Pembuatan, Tata Cara Pembetulan Atau Penggantian, Dan Tata Cara Pembatalan Faktur Pajak.

PER-16/PJ/2014 (berlaku sejak 1 Juli 2014) tentang Tata Cara Pembuatan dan Pelaporan Faktur Pajak Berbentuk Elektronik.

Prahaji, Maulana, dkk. 2015. Analisis Penerapan Elektronik Nomor Faktur Sebagai Upaya Untuk Mencegah Penerbitan Faktur Pajak Fiktif (Suatu Studi Pada KPP Wajib Pajak Besar Tiga). Jurnal Administrasi Bisnis - Perpajakan (JAB) Vol. 5 No. 1 April 2015. Diakses dari http://perpajakan.studentjournal.ub.ac.id (08 Januari 2016).

Resmi, Siti. 2014. Perpajakan Teori \& Kasus. Edisi 6. Buku 2. Jakarta: Salemba Empat. 
Rizqiah, Firda Ayu, dkk. 2014. Implementasi Elektronik Nomor Faktur (E-Nofa) Pajak Dalam Upaya Meningkatkan Pelaporan Wajib Pajak (Studi Pada Pegawai Pajak Di KPP Pratama Surabaya Genteng). Jurnal Administrasi Bisnis - Perpajakan (JAB) Vol. 2 No. 1 April 2014. Diakses dari http://perpajakan.studentjournal.ub.ac.id (08 Januari 2016).

Sagita, Fadilla. 2013. Peranan Pajak Kendaraan Alat Berat Dalam Penerimaan Pajak Daerah Di Unit Pelaksana Teknis (Upt) Pendapatan Kabupaten Kampar Dinas Pendapatan Provinsi Riau. Riau, http://repository.uinsuska.ac.id/3280/1/2013_201350AD P.pdf, Diakses pada tanggal 02 Mei 2016).

Sari,Vebrina. 2012. Tingkat Kepatuhan Wajib Pajak Badan Usaha Mikro Kecil dan Menengah Pasca Kebijakan Fasilitas Pengurangan Tarif PPh di KPP Pratama Jakarta Kebayoran Lama. Skripsi. 17 Januari 2012. Diakses dari http://digilib.ui.ac.id (08 Januari 2016). SE - 29/PJ.53/2003 SE-29/PJ.53/2003 tanggal 4 Desember 2003 tentang Langkah-langkah Penanganan Atas Penerbitan dan Penggunaan Faktur Pajak Tidak Sah.

Suandy, Erly. 2014. Hukum Pajak. Yogjakarta. Salemba Empat.

Sugiyono. 2012. Metode Penelitian Kuantitatif Kualitatif dan R\&D. Bandung: Alfabeta.

Sucipto. 2014. Menkeu Atur Pemberlakuan Faktur Pajak Elektronik. Warta Ekonomi. 16 Januari 2014. Diakss dari http://wartaekonomi.co.id/berita22904/menkeu-aturpemberlakuan-faktur-pajak-elektronik.html (22 Desember 2015).

Trilaksana, M. Gugus. 2013. Efektifitas Penggunaan Drop Box Dan Elektronic Filling (EFilling) Sistem Untuk Meningkatkan Kepatuhan Pelaporan Spt Tahunan Pajak Penghasilan Wajib Pajak Orang Pribadi. Skripsi. Universitas Islam Negeri Maulana Malik Ibrahim Malang.

Undang-Undang No. 16 Tahun 2009 tentang Ketentuan Umum dan Tata Cara Perpajakan.

Undang-Undang Nomor 42 Tahun 2009 tentang Pajak Pertambahan Nilai Barang dan Jasa dan Pajak Penjualan atas Barang Mewah.

Waluyo. 2011. perpajakan Indonesia. Jakarta: Salemba Empat.

Waluyo. 2012. Akuntansi Pajak. Jakarta: Salemba Empat

Widodo, Arie, dkk. 2015. e-faktur: suatu aplikasi berbagai manfaat. artikel. 21 Juli 2015. Diakses dari http://ortax.org (22 Desember 2015). 